\title{
Akt signaling as a mediator of cardiac adaptation to low birth weight
}

\author{
Kimberley C W Wang', Kimberley J Botting', Song Zhang1, I Caroline McMillen', \\ Doug A Brooks² and Janna L Morrison'1
}

${ }^{1}$ Early Origins of Adult Health Research Group, School of Pharmacy and Medical Sciences, Sansom Institute for Health Research, University of South Australia, Adelaide, South Australia, Australia 2Mechanisms in Cell Biology and Disease Research Group, School of Pharmacy and Medical Sciences, Sansom Institute for Health Research, University of South Australia, Adelaide, South Australia, Australia

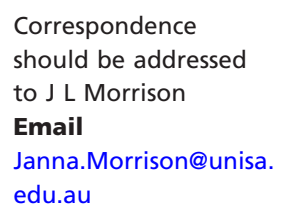
should be addressed to J L Morrison Email Janna.Morrison@unisa. edu.au

\begin{abstract}
Intrauterine insults, such as poor nutrition and placental insufficiency, can alter cardiomyocyte development, and this can have significant long-term implications for heart health. Consequently, epidemiological studies have shown that low-birthweight babies have an increased risk of death from cardiovascular disease in adult life. In addition, intrauterine growth restriction can result in increased left ventricular hypertrophy, which is the strongest predictor for poor health outcomes in cardiac patients. The mechanisms responsible for these associations are not clear, but a suboptimal intrauterine environment can program alternative expression of genes such as cardiac IGF-2/H19, IGF-2R and $A_{1}{ }_{1} R$ through either an increase or decrease in DNA methylation or histone acetylation at specific loci. Furthermore, hypoxia and other intrauterine insults can also activate the IGF-1 receptor via IGF-1 and IGF-2, and the $\mathrm{AT}_{1}$ receptor via angiotensin signaling pathways; both of which can result in the phosphorylation of Akt and the activation of a range of downstream pathways. In turn, Akt activation can increase cardiac angiogenesis and cardiomyocyte apoptosis and promote a reversion of metabolism in postnatal life to a fetal phenotype, which involves increased reliance on glucose. Cardiac Akt can also be indirectly regulated by microRNAs and conversely can target microRNAs that will eventually affect other specific cardiac genes and proteins. This review aims to discuss our understanding of this complex network of interactions, which may help explain the link between low birth weight and the increased risk of cardiovascular disease in adult life.
\end{abstract}

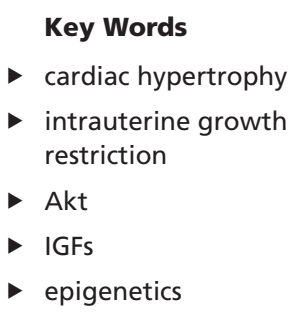

Journal of Endocrinology (2017) 233, R81-R94

\section{Association between low birth weight and cardiovascular disease}

Cardiovascular disease is the world's leading cause of mortality, equating to 17.5 million deaths per year, which is projected to increase to 22.2 million deaths per year by 2030 (WHO 2014). Large-scale epidemiological studies have shown that low birth weight is associated with an increase in the age-adjusted relative risk for cardiovascular disease (Barker et al. 1989, Osmond et al. 1993, Fall et al. 1995a,b,
Rich-Edwards et al. 1997). This association is independent of the recognized lifestyle-related cardiovascular disease risk factors, such as smoking, ethnicity, body mass index and socioeconomic grouping (Rich-Edwards et al. 1997).

In a cohort of 13,249 English men from Hertfordshire and Sheffield, those who had low birth weight and remained small at 1 year of age had 3 times the risk of death

This article is adapted from work presented at the Aspen/Snowmass Perinatal Biology Symposium, 27-30 August 2016. The meeting was supported in part by the Journal of Endorsinologyled from Bioscientifica.com at 04/26/2023 07:54:25AM 
from cardiovascular disease than males who were heavier at 1 year of age (Barker et al. 1989). Additional studies have confirmed that there is a significant and specific inverse relationship between birth weight and the risk of cardiovascular disease in adulthood (Osmond et al. 1993, Rich-Edwards etal. 1997, Leon etal. 1998, Huxley etal. 2007). In humans, reduced growth before birth is also associated with altered left ventricular mass (Vijayakumar et al. 1995), with intrauterine growth-restricted (IUGR) fetuses having a larger heart relative to their body weight (Veille et al. 1993). Furthermore, the altered left ventricular hypertrophy was transmitted to the F2 offspring in rats, indicating transgenerational programming effects of IUGR (Master et al. 2014). Left ventricular hypertrophy in adulthood is also associated with deleterious cardiovascular disease outcomes (Levy et al. 1988, 1989, 1990), prompting studies to understand the molecular basis of this association and the impact on cardiac growth and maturation. Some of the physiological mechanisms underlying the association between suboptimal growth during gestation or low birth weight and later life cardiovascular disease are known, but many questions remain. This review explores insulin-like growth factor 1 receptor (IGF-1R), insulin-like growth factor 2 receptor (IGF-2R) and angiotensin II type 1 receptor $\left(\mathrm{AT}_{1} \mathrm{R}\right)$-mediated Akt signaling as molecular foundations for the association between low birth weight and cardiovascular disease in adulthood.

\section{Cardiomyocyte development during fetal life}

Cardiogenesis is the process in which the heart is formed from progenitor cells including looping and septation. During early gestation, after cardiogenesis, mononucleated cardiomyocytes increase the mass of the heart by hyperplastic growth (Burrell et al. 2003, Jonker et al. 2007b, Botting et al. 2012, Jonker \& Louey 2016). This is followed by a transition period during which there is a decline in the proportion of mononucleated cardiomyocytes and a corresponding increase in the proportion of cardiomyocytes that are binucleated or polyploid (Burrell et al. 2003, Jonker et al. 2007b). Binucleation occurs when mononucleated cardiomyocytes undergo DNA synthesis and nuclear mitosis without cytokinesis (Li et al. 1997a,b, Jonker et al. 2007a, Jonker \& Louey 2016). These binucleated cardiomyocytes do not proliferate and subsequent increases in cardiac mass occur via hypertrophy of binucleated or polyploid cardiomyocytes (Smolich et al. 1989, Lumbers et al. 2005, Botting et al. 2012). Interestingly, this process begins before birth in some species, such as humans and sheep, but after birth in other species such as mice and rats (Botting et al. 2012). This is important because it is in late gestation when complications in pregnancy such as placental insufficiency may impact on cardiomyocyte endowment in the human (Fig. 1), and thus, studies in an animal model where the maturation of cardiomyocytes occurs at the same time as in the human are likely to be the most informative. Furthermore, although there is some capacity for renewal of cardiomyocytes during childhood and adolescence in humans (Bergmann et al. 2009, 2015, Mollova et al. 2013), the capacity to repair after damage is very limited after birth (Fratz et al. 2011). Therefore, any insults to the heart during this developmental transition period can have a lifelong effect, especially as cardiomyocytes begin withdrawing from the cell cycle at around the time of birth. In IUGR, there are fewer cardiomyocytes in the fetus and offspring (Stacy et al. 2009, Black et al. 2012,

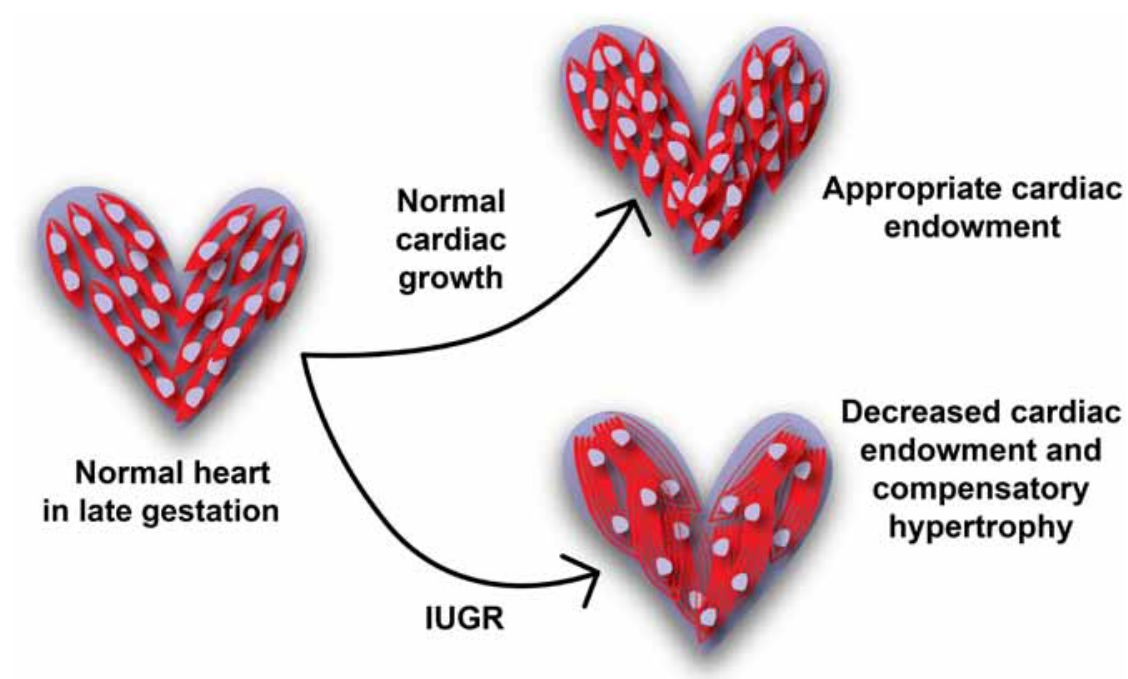

Figure 1

IUGR decreases cardiomyocyte endowment and the reduced number of cardiomyocytes in the heart are forced to undergo hypertrophy to maintain cardiac function (Morrison et al. 2007, Wang et al. 2011, Black et al. 2012, Botting et al. 2014, Master et al. 2014). 
Botting et al. 2014), which may limit the potential of the heart to adapt to changes in supply of nutrients and oxygen in fetal life or to changes in load after birth. Thus, to maintain homeostasis, the fetal heart adapts to continued environmental insults through compensatory hypertrophy that may begin as physiological (Bae et al. 2003, Morrison et al. 2007, Thornburg et al. 2008, Wang et al. 2011, Botting et al. 2014), but proceed to pathological later in life (Vijayakumar et al. 1995, Master et al. 2014), and thus, lead to health consequences in adult life.

Cardiomyocyte growth is determined by a range of hormones and signaling pathways. The insulin-like growth factor (IGFs) and renin-angiotensin system (RAS) signaling pathways play vital roles in heart growth and the overall growth of the fetus. In fetal life, the IGF-1R signaling pathway has been implicated in physiological growth of the heart, which can involve both proliferation and hypertrophy (Sundgren et al. 2003, Lumbers et al. 2009, Wang et al. 2011). The IGF-2R was once viewed as only a clearance receptor for plasma IGF-2 (Kornfeld 1992, Powell et al. 2006) but is now acknowledged to induce cardiac hypertrophy (Chu et al. 2008, Wang et al. $2011,2012 a, b)$. Additionally, the RAS also plays a role in cardiac hypertrophy (Ichihara et al. 2001) and regulates factors involved in capillary formation (Yazawa et al. 2011), autophagy (Porrello et al. 2009) and fibrosis (Domenighetti et al. 2005). The activities of both the IGF and RAS signaling pathways can be moderated by epigenetic mechanisms, such as DNA methylation, histone acetylation and microRNA (miR), which will be discussed later in this review. Furthermore, the activation of both of these signaling pathways can regulate the activity of downstream proteins such as protein kinase $\mathrm{B}$ (Akt). Akt is a serine/threonine protein kinase that plays a central role in regulating different aspects of heart growth (Fig. 2), which determine the number (proliferation, apoptosis and autophagy), size (hypertrophy) and metabolic activity (Datta et al. 1997, Donthi et al. 2000, DeBosch et al. 2006, Chang et al. 2010, Hua et al. 2011) of cardiomyocytes. We will review the effects of each of these signaling pathways on cardiac growth and on downstream proteins, their possible regulation through epigenetic mechanisms, and their roles in mediating the effects of IUGR on cardiac development in the fetus and cardiac health in postnatal life.

\section{Akt is epigenetically regulated in several ways}

\section{Impact of DNA methylation of IGF-2/H19, IGF-2R and $A T_{1} R$ genes on Akt}

Epigenetic changes involve modifications that either interfere with the binding of transcription activators or repressors to specific gene promoters and/or changes in the structure of chromatin (Ptak \& Petronis 2008). Epigenetic changes occur in response to environmental and behavioral influences, such as nutrition and smoking (Mathers et al. 2010) and are responsible for inducing stable inheritable changes in gene expression that are potentially reversible (Kiefer 2007), but may also promote a transgenerational phenotype (Hanson \& Skinner 2016). A suboptimal intrauterine environment can lead

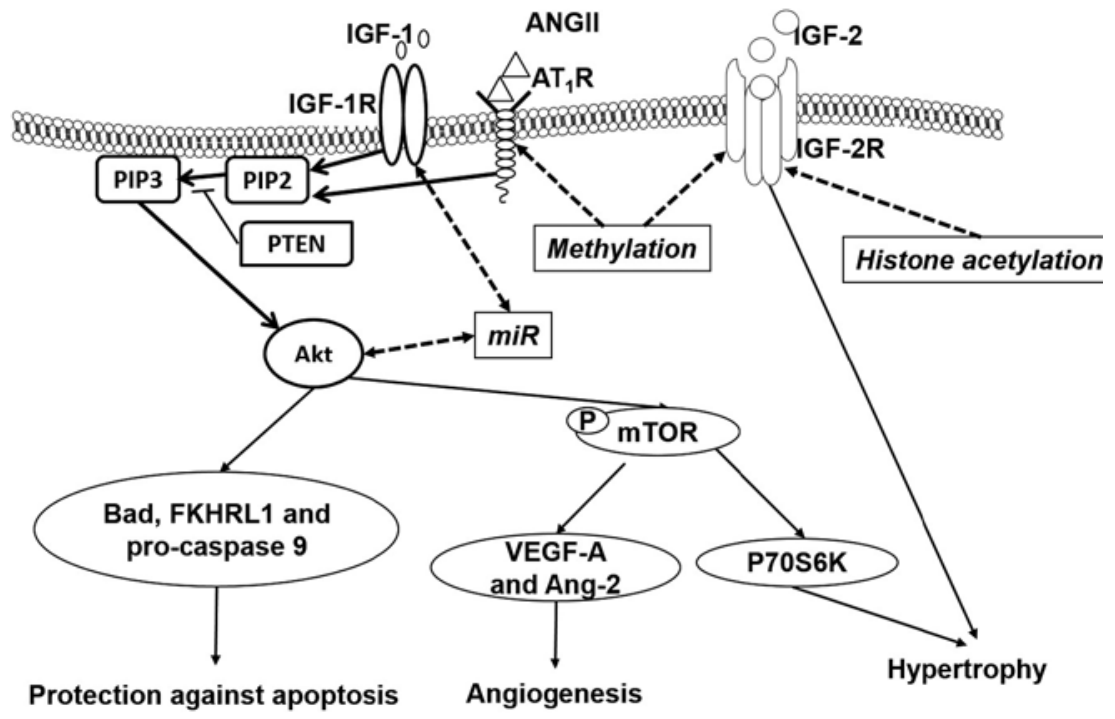

Figure 2

The impact of epigenetic regulation (miR, DNA methylation and histone acetylation) of IGR-1R, IGF-2R, AT ${ }_{1} R$ and Akt on cardiac growth and development (Datta et al. 1997, Brunet et al. 1999, Bartel 2004, Shiojima et al. 2005, Wang et al. 2015a,b). 
to epigenetic changes in IGF-2/H19, IGF-2R in various tissues, such as the placenta (for further details, please read Young et al. 2001, Reik et al. 2003, Dolinoy et al. 2007) and $A T_{1} R$ of the liver (Tosh et al. 2010). In human adults that were born growth restricted; for example, there is increased methylation at the differentially methylated region (DMR) 2 of the IGF-2R, in DNA from the peripheral blood lymphocytes of adults compared to individuals that were born a normal birth weight (Turner et al. 2010). It was hypothesized that the increased methylation at DMR 2 of $I G F-2 R$ in growth-restricted individuals resulted in increased IGF-2R gene expression, which could lead to a decrease in circulating IGF-2 and thus decreased growth (Turner et al. 2010). Changes in the DNA methylation status of the IGF-2/H19 and IGF-2R genes due to a suboptimal intrauterine environment have also been found in sheep adrenals (Zhang et al. 2010) and human HUVEC and endothelial cells (Ollikainen et al. 2010).

Although DNA methylation may be involved in cardiac pathogenesis, the significant increases in cardiac IGF-2 and IGF-2R mRNA expression in low-birth-weight lambs before and after birth were not due to changes in the DNA methylation at the DMR within the intron 2 of IGF-2R (Wang et al. 2011). Rat models of left ventricular hypertrophy, including angiotensin II (ANGII) infusion or spontaneous hypertension, are also associated with increased cardiac IGF-2R gene expression. However, this was not due to changes in DNA methylation either, at least not for the DMR within the promoter of intron 1 nor within intron 2 in the IGF-2R (Chu et al. 2012). In the IUGR fetus experiencing hypoxemia in utero, the increase in IGF-2 and IGF-2R mRNA expression may be a response to chronic hypoxemia; however, this would not be the case in the low-birth-weight lamb after birth because it is normoxemic. In addition, we found decreased cardiac $\mathrm{AT}_{1} \mathrm{R}$ protein in low-birth-weight lambs with no change in $A T_{1} R$ promoter DNA methylation or $\mathrm{AT}_{1} \mathrm{R}$ mRNA expression (Wang et al. 2015a). These findings suggested that DNA methylation was not involved in the cardiac hypertrophy in response to hypoxemia, but rather that other epigenetic mechanisms may be responsible for the increased expression of these genes before birth and that are maintained after birth.

\section{Histone acetylation on IGF-2 and IGF-2R gene expression and Akt}

Hypoxia can induce histone acetylation, specifically at histone 3 lysine 9 (H3K9) and histone 4 lysine 8 (H4K8) (Johnson et al. 2008, Bouquet et al. 2011), opening the chromatin, making the DNA available for transcription and resulting in increased mRNA expression (Fig. 3). This effect

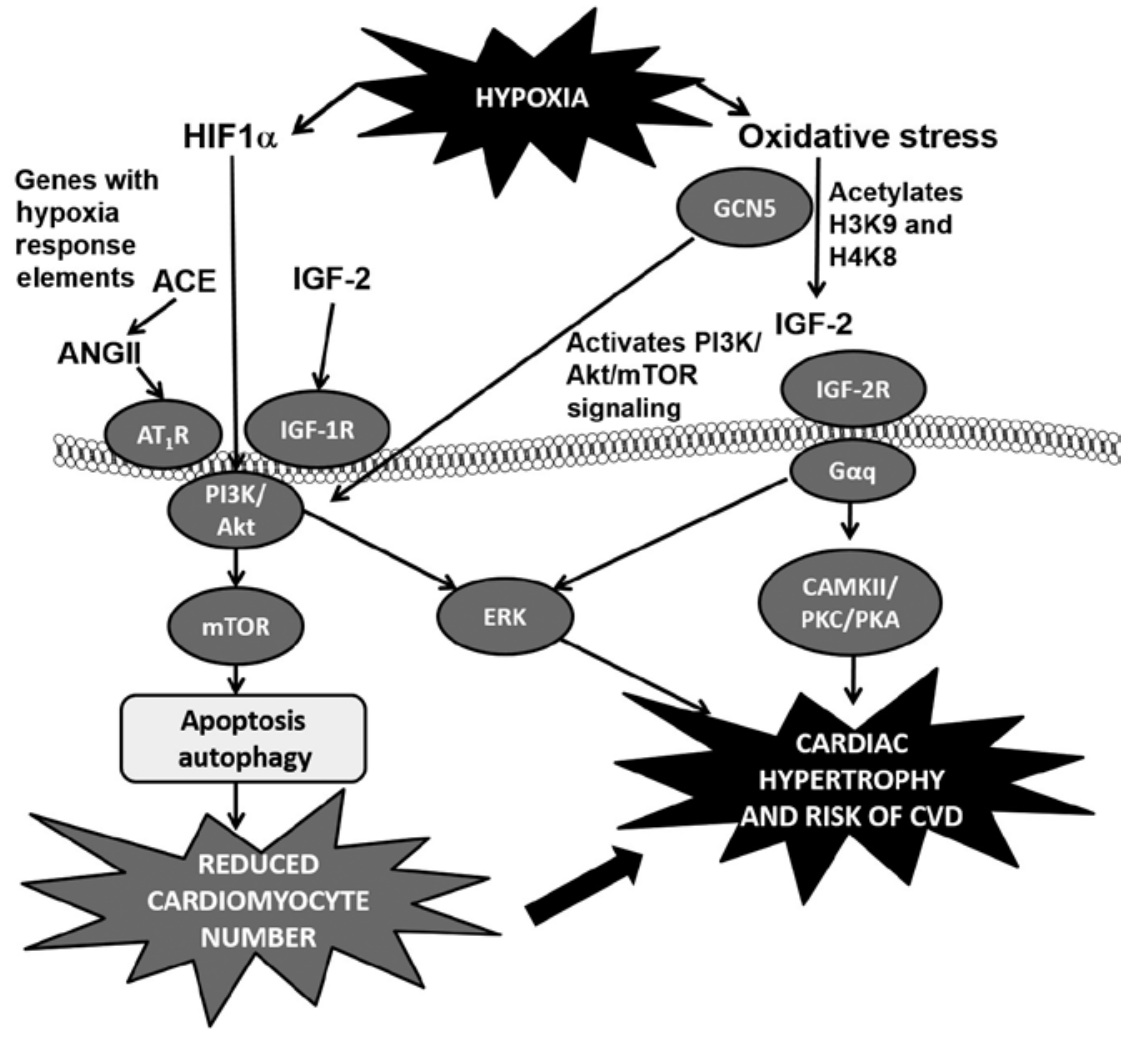

Figure 3

HIF1 $\alpha$ and reactive oxygen species induce cardiac protein acetylation (Grandjean et al. 2001b, Patterson et al. 2010, Bouquet et al. 2011, Guo et al. 2011, Wang et al. 2015b). 
is persistent, but reversible (Jeppesen 1997, Smith et al. 2002, VerMilyea et al. 2009, Fernandez-Gonzalez et al. 2010), which is important from a therapeutic viewpoint, if this is the hypoxia-induced mechanism that leads to cardiac hypertrophy. Hypoxia-inducible factor (HIF)- $1 \alpha$ can activate the demethylase protein jumonji domain containing 1A (JMJD1a), which demethylates H3K9 residues and allows them to be acetylated by histone acetylases (Mimura et al. 2011). HIF-1 $\alpha$ also acts through Akt to increase the expression of GCN5, a histone acetyltransferase that targets genes with a specific H3K9 and H4K8 sequence (Kuo et al. 1996, Maeng et al. 2009, Guo et al. 2011, Jin et al. 2011). Hypoxia increases reactive oxygen species (ROS) generation (Patterson et al. 2010), and the accumulation of ROS under oxidative stress can also increase protein acetylation in the heart (Thompson \& Al-Hasan 2012, Horton et al. 2016). The elements of these pathways that result in histone acetylation may therefore be responsible for the altered expression of genes encoding growth factors and receptors, which activate the signaling pathways associated with hypoxia-induced cardiac hypertrophy.

If gene methylation is not a factor in hypoxia-induced pathogenesis, then histone acetylation of cardiac IGF-2, $I G F-2 R$ and $A T_{1} R$ may be the underlying mechanism linking low birth weight to poor cardiovascular health in adult life. There is evidence linking altered histone acetylation with increased cardiac expression of IGF-2/ IGF-2R and Akt signaling in response to hypoxia. For example, ANGII-induced hypertrophy in the rat heart increases IGF-2R gene expression specifically through histone acetylation at $\mathrm{H} 3 \mathrm{~K} 9$ and histone 4, and not through the methylation of the DMRs in IGF-2R promoter, intron 1 or 2 (Chu et al. 2012). Furthermore, IGF-2 and IGF-2R gene expression patterns are more closely related to the acetylation of H3K9 and H4K8 ( $\mathrm{Hu}$ et al. 2000, Grandjean et al. 2001, Vu et al. 2004, Singh et al. 2010) than to methylation status (Yang et al. 2003). Interestingly, despite an increase in cardiac gene expression of IGF-2 and $I G F-2 R$ in the chronically hypoxemic sheep fetus in late gestation (Wang et al. 2011), there is no evidence that the heart is hypoxic at this stage of gestation, as there was no change in gene expression of HIF1 $\alpha$ or its target genes (Botting et al. 2014). However, the heart may have been hypoxic earlier in gestation. Thus, a response to hypoxia in early gestation may result in altered gene expression that persists into postnatal life. Thus, it is important to understand at what stage in gestation the fetal heart has responded to hypoxia or ROS and if hypoxia or ROS are the underlying mediator of changes in cardiac IGF-2/IGF-2R expression leading to an increased risk of left ventricular hypertrophy.

We have found increased acetylation of histone H3K9 of the IGF-2R promoter and IGF-2R intron $2 \mathrm{DMR}$ in the hearts of low-birth-weight lambs compared to average-birth-weight lambs (Wang et al. 2015b). These observations may explain the increase in the gene expression of IGF-2R (Wang et al. 2011) and result in IGF-2R activation of the downstream Gaq signaling pathway (Wang et al. 2015b) as well as left ventricular hypertrophy (Wang et al. 2011), which was observed in the low-birth-weight lamb. In addition, we reported decreased acetylation of the histone H3K9 $A T_{1} R$ promoter, which may explain the decreased cardiac $\mathrm{AT}_{1} \mathrm{R}$ protein abundance observed in low-birth-weight lambs (Wang et al. 2015a). Although histone acetylation may be important in altering the expression of cardiac IGF-2, IGF-2R and $\mathrm{AT}_{1} \mathrm{R}$ of the IUGR fetus and/or low-birthweight lamb, there is evidence that the IGF-1R, IGF-2R and $\mathrm{AT}_{1} \mathrm{R}$ signaling pathways involving Akt, are also regulated by specific miR, which are short, noncoding RNA molecules that cause gene silencing by inhibiting mRNA translation or promoting mRNA degradation and have been implicated in cardiac development and disease (Porrello 2013). We have previously investigated the changes in sheep cardiac miRs across late gestation and early postnatal life that suggests a coordinated and complex role of multiple miRNA in the regulation of cardiomyocyte quiescence (Morrison et al. 2015). Such miRs may be an important component of the regulatory process contributing to an increase in cardiac IGF-1R, IGF-2R, $\mathrm{AT}_{1} \mathrm{R}$ and Akt signaling in response to chronic hypoxemia in the IUGR fetus.

\section{Impact of a suboptimal intrauterine environment and miRs on Akt}

microRNA-378 is abundant in the rat cardiomyocytes, and it can directly target IGF-1R and subsequent downstream signaling of Akt, which is associated with postnatal cardiac remodeling and cardiomyocyte survival during stress (Knezevic et al. 2012). We have also previously shown that the expression of miR-378 increased from 90-day gestation to 173 days after birth in sheep (Morrison et al. 2015). Many other miRs also target IGF-1R in other tissues (Huang et al. 2011, Gao et al. 2014, Wang et al. 2014). In vitro cardiac fibroblast studies have also shown that $\mathrm{AT}_{1} \mathrm{R}$ can regulate various miRs (Jeppesen et al. 2011) and also appear to be a target of the miR-132/212 family (Eskildsen et al. 2015).

Published by Bioscientifica Ltd. 
The significant increase of Akt in the hearts of lowbirth-weight compared to average-birth-weight lambs in the absence of increased IGF-1R (Wang et al. 2011), but decreased $\mathrm{AT}_{1} \mathrm{R}$ (Wang et al. 2015a), suggests that Akt may be epigenetically programmed in a suboptimal intrauterine environment. However, there are no data to suggest that hypoxia activates Akt through histone acetylation, but there is evidence that miR may be involved (Bartel 2004). miR plays important roles in cardiac development (Tatsuguchi et al. 2007, Porrello et al. 2011) and equally in heart failure (Ikeda et al. 2007, Thum et al. 2007).

Akt exists in different isoforms (Akt1, Akt2 and Akt3), which have been identified as a direct target of specific miRs (Fig. 2). For example, Lin and coworkers have shown that Akt1 is a direct target of miR-149* (Lin et al. 2010) and that miR-149* represses Akt1 to induce apoptosis in vitro in human cancer cells (Lin et al. 2010). It is more likely that miR regulates Akt2 rather than Akt1, as Akt2 has been demonstrated to be a direct target for a range of miR including miR-203 in a bladder cancer cell line (Saini et al. 2011) and miR-184 in neuroblastoma cell lines (Foley et al. 2010). Akt3 appears to be a direct target of miR-519d, as demonstrated in hepatocellular carcinoma cells (Fornari et al. 2012). Using a heart failure rat model, miR-133a was shown to improve cardiac function and reduce fibrosis via the inhibition of Akt (Sang et al. 2015). Thus, further work is required to establish if there is a direct link between miR and cardiac Akt expression in response to hypoxia.

miRs can also regulate Akt signaling indirectly by targeting genes that can inhibit or stimulate Akt (Fig. 2). For example, overexpression of cardiac miR-494 leads to decreased abundance of pro-apoptotic proteins such as Rhoassociated, coiled-coil containing protein kinase 1 (ROCK1), phosphatase and tensin homolog (PTEN), $\mathrm{Ca}^{2+} /$ calmodulindependent protein kinases II $\delta$ (CaMKIIס), as well as the anti-apoptotic proteins fibroblast growth factor receptor 2 (FGFR2) and leukemia inhibitory factor (LIF) (Wang et al. 2010). The overexpression of these proteins can increase phospho-Akt abundance and thus downstream targets of Akt to reduce ischemia/reperfusion injury (Wang et al. 2010). Thus, suppression of these proteins by the action of miR-494 reduces phospho-Akt abundance and ultimately the protective effects of Akt targets against ischemic injury. miR-378 can directly target IGF-1R resulting in its inhibition and thus a reduction in Akt signaling (Knezevic et al. 2012). PTEN, a phosphatidylinositol (PI)-3-kinase (PI3K)/ Akt antagonist that acts through dephosphorylation of phosphoinositide-3,4,5-triphosphate, an upstream effector of Akt, is a direct target of many miRs, resulting in the inhibition of Akt signaling (Shiojima \& Walsh 2006). miRs that can target PTEN include miR-21 (Sayed et al. 2010, Dey et al. 2012, Kumarswamy et al. 2012b), miR-205 (Qu et al. 2012), miR-221/222 (Garofalo et al. 2009), miR-216a/217 (Kato et al. 2009), miR-26b, miR-128 (Palumbo et al. 2013) and miR-486 (Small et al. 2010), all of which were expressed in the sheep heart from midgestation to 173 days after birth (Morrison et al. 2015). These studies demonstrate the potential of manipulating Akt using a specific miR to either stimulate or inhibit Akt signaling.

Interestingly, Akt can also regulate its downstream targets through epigenetic mechanisms, creating several steps for epigenetic regulation of the activity of Akt. For example, in breast cancer cell lines with higher Akt1 activity, there is epigenetic silencing of PI3K/Aktregulated loci through either trimethylation of H3K27 or DNA methylation (Zuo et al. 2011). Akt regulates miR210 through a HIF-independent mechanism in hypoxic cultured cardiomyocytes (Mutharasan et al. 2011). Furthermore, Akt can also upregulate miR-21, resulting in the inhibition of pro-apoptotic genes such as Fas ligand and PTEN in these hypoxic cardiomyocytes (Sayed et al. 2010). In addition, constitutively active Akt was induced in cultured cardiomyocytes by a 70\% reduction in miR199a-5p expression. This inhibition of miR199a-5p resulted in an increase in the expression of its target genes, HIF- $1 \alpha$ and Sirt1, both of which promote cardiomyocyte survival (Rane et al. 2010). Therefore, Akt plays a major role in modulating anti-apoptotic pathways in cardiac ischemia preconditioning (Sayed \& Abdellatif 2010). Akt phosphorylation in chronic failing hearts is accompanied by FoxO3a phosphorylation, which is responsible for decreased miR-1 expression (Kumarswamy et al. 2012a). The repression of miR-1 in failing hearts can be normalized by AAV9.SERCA2a treatment via reversal of the phosphorylated Akt-FoxO3a axis (Kumarswamy et al. 2012a). In HeLa and 293T cell lines, Akt can also modulate the stability of DNA methyltransferase (DNMT) 1 protein (Sun et al. 2007), a protein that maintains methylation at genomic imprints during preimplantation development (Branco et al. 2008). In addition, Akt enhances DNMT 1 stability and maintains DNA methylation and chromatin structure in HeLa and 293T cell lines (Sun et al. 2007). Collectively, this shows that Akt is integrally involved in epigenetic regulation both of its own activity and as a consequence of its impact on targets through different epigenetic mechanisms. Consequently, there 
are many targets for programming a lifelong change in the expression of specific genes, which can regulate the growth of cardiomyocytes not only in fetal life but also after birth, potentially influencing cardiovascular risk in adult life.

\section{Cardiac Akt has roles in multiple signaling pathways that mediate multiple effects in the heart of the IUGR fetus}

\section{Impact of IUGR on Akt-mediated cardiomyocyte growth}

Activation of Akt results in downstream activation of hypertrophic factors such as P70S6K, which is dependent on the mammalian target of rapamycin (mTOR; Fig. 2). Activation of mTOR leads to the activation of angiogenic factors, vascular endothelial growth factor-A (VEGF-A) and angiopoietin-2 (Ang-2) (Shiojima et al. 2005). In terms of the impact of IUGR on cardiomyocyte growth, we have shown a delay in binucleation of cardiomyocytes in IUGR fetuses. Associated with this delay in binucleation, we have observed an increase in the expression of molecules involved in hypertrophy in the IUGR fetus that persists in the low-birth-weight lamb, which have increased left ventricle relative to body weight (Wang et al. 2011). We have speculated that in fetal life, IGF-1R mediates the delay in binucleation, whereas IGF-2R mediates the increase in hypertrophy of cardiomyocytes (Wang et al. 2011). In average-birth-weight lambs, IGF-2R appears to play the traditional clearance role. However, in lowbirth-weight lambs, there was increased Akt (Wang et al. $2015 a$ ), and this IGF-2R $\mathrm{G}_{\alpha \mathrm{q}}$ signaling may be responsible for the increased left ventricular hypertrophy (Wang et al. $2011,2015 b$ ). These data show that a suboptimal in utero environment alters the expression of different receptors with the subsequent activation of signaling pathways that may alter the phenotype of the heart.

\section{Akt increases angiogenesis to match cardiomyocyte endowment}

A transient increase in Akt activity has been shown to increase protein levels of VEGF-A and Ang-2, coupled with an increase in capillary density (Shiojima et al. 2005). However, prolonged expression of Akt, as observed in pathological hypertrophy, does not increase either of these angiogenic growth factors and decreases capillary density (Shiojima et al. 2005). This suggests that angiogenesis can initially support hypertrophy, but is not maintained with the advent of excessive hypertrophy, and this absence of compensatory angiogenesis appears to be due to increased Akt activity (Shiojima et al. 2005). In rats, prenatal glucocorticoid-induced IUGR resulted in increased Akt activity in 24-week offspring (Langdown et al. 2001). Tenweek-old rats that were exposed to chronic hypoxia in utero had decreased capillary density and impaired cardiac relaxation, but their cardiac contractile performance was increased (Hauton \& Ousley 2009). On the other hand, transgenic mice with overexpression of cardiac ANGII have decreased capillary density (Xu et al. 2007). In 21-day low-birth-weight lambs with left ventricular hypertrophy, there is a decrease in total capillary length compared with average birth weight lambs due to increased cardiac ANGII and increased Akt signaling (Wang et al. 2015a).

Studies in models of pathological hypertrophy have investigated mechanisms to correct the mismatch between cardiomyocyte size and capillary density. Rapamycin administration, which blocks Akt activity through mTOR, attenuates the hypertrophy induced by pressure overload and subsequently improves contractile function (McMullen et al. 2004). Furthermore, angiogenic growth factor VEGF-A treatment of newborn rabbits that have pressure overload-induced hypertrophy decreases apoptosis of cardiomyocytes, preserves contractile function and reduces the incidence of death due to heart failure (Friehs et al. 2006). Consequently, by reducing the volume of cardiomyocytes or increasing the volume of coronary capillaries, contractile function is improved and apoptosis is reduced. These studies highlight the importance of maintaining the optimum ratio of cardiomyocyte to capillary volume, but this optimum is lost in pathological hypertrophy and can be induced either by ANGII or low birth weight.

\section{Role of Akt in mediating IUGR-induced apoptosis}

There is increased vulnerability to ischemia/reperfusion injury in rats exposed to prenatal hypoxia, which may be due to decreased protection against apoptosis (Li et al. 2003). Apoptosis is a programmed cellular death that can be activated by a wide range of physiological and pathophysiological events, including an extrinsic or intrinsic pathway (for further details, please read Saraste \& Pulkki 2000, van Heerde et al. 2000, Botting et al. 2012). Akt can influence apoptosis through its actions on at least three different molecules (Fig. 2), some of which are also altered in IUGR. Akt is responsible for the phosphorylation of Bad (Datta et al. 1997, 
del Peso et al. 1997), a member of the Bcl-2 family and promotes apoptosis through heterodimerization with anti-apoptotic $\mathrm{Bcl}-\mathrm{X}_{\mathrm{L}}$, neutralizing the protective effect of Bcl- $\mathrm{X}_{\mathrm{L}}$ in blocking cytochrome $\mathrm{C}$ release from the mitochondria. Phosphorylation of Bad, however, results in Bad dimerization with 14-3-3, preventing its association with Bcl- $\mathrm{X}_{\mathrm{L}}$ (Zha et al. 1996). Activation of Akt also results in the phosphorylation of a member of the FKHRL1, which promotes the expression of Fas (death ligand) and other genes that are critically involved in apoptosis. Phosphorylation of FKHRL1 leads to its association with 14-3-3 proteins and retention in the cytoplasm (Brunet et al. 1999). Akt also phosphorylates pro-caspase 9 directly, preventing its cleavage by cytochrome $\mathrm{C}$ and subsequent 'effector' caspase activity (Cardone et al. 1998).

In the absence of phosphorylation of these proapoptotic factors by Akt, apoptosis will be increased, which has direct implications for cardiomyocyte endowment in the developing heart because cardiomyocyte endowment, the complement of heart cells that an individual will have for life, is determined before or around birth in humans and sheep, but after birth in rodents. We have previously shown that in sheep fetuses exposed to chronic hypoxemia throughout gestation, there was a reduced number of total cardiomyocytes in the IUGR fetuses, but no change in the percentage of apoptotic cardiomyocytes or Bcl-2 and Bax mRNA expression (Botting et al. 2014).
In contrast, fetal rats exposed to maternal hypoxia in the last week of gestation had a greater percentage of apoptotic cardiomyocytes (Bae et al. 2003). Therefore, it seems that the timing of gestational insult may play a bigger role in programming cardiac apoptosis.

\section{Impact of IUGR on Akt-mediated metabolism}

Glucose is the substrate predominantly utilized by the fetal heart for energy metabolism, with ATP production being derived mainly from anaerobic glycolysis (Lopaschuk et al. 1991). Akt mainly regulates glucose transporter (GLUT)-1 gene expression (Fig. 4), particularly by Akt-dependent activation of mTOR complex 1 (Manning \& Cantley 2007). On the other hand, cardiac Akt is important for the translocation of GLUT-4 as Akt can also be activated by the insulin receptor (IR), leading to the inhibition of Akt substrate 160 (AS160), which then stimulates the translocation of GLUT-4-containing vesicles to the sarcolemma for the transport of glucose into cardiomyocytes (Sano et al. 2003). However, a rapid shift from glucose to fatty acid metabolism occurs in the postnatal period, where thereafter fatty acids contribute $~ 70 \%$ of the total ATP generated (Lopaschuk et al. 2010).

In animal models of fetal growth restriction (Langdown et al. 2001, Tappia et al. 2005, Chan et al. 2009) and ventricular hypertrophy (Iemitsu et al. 2003,

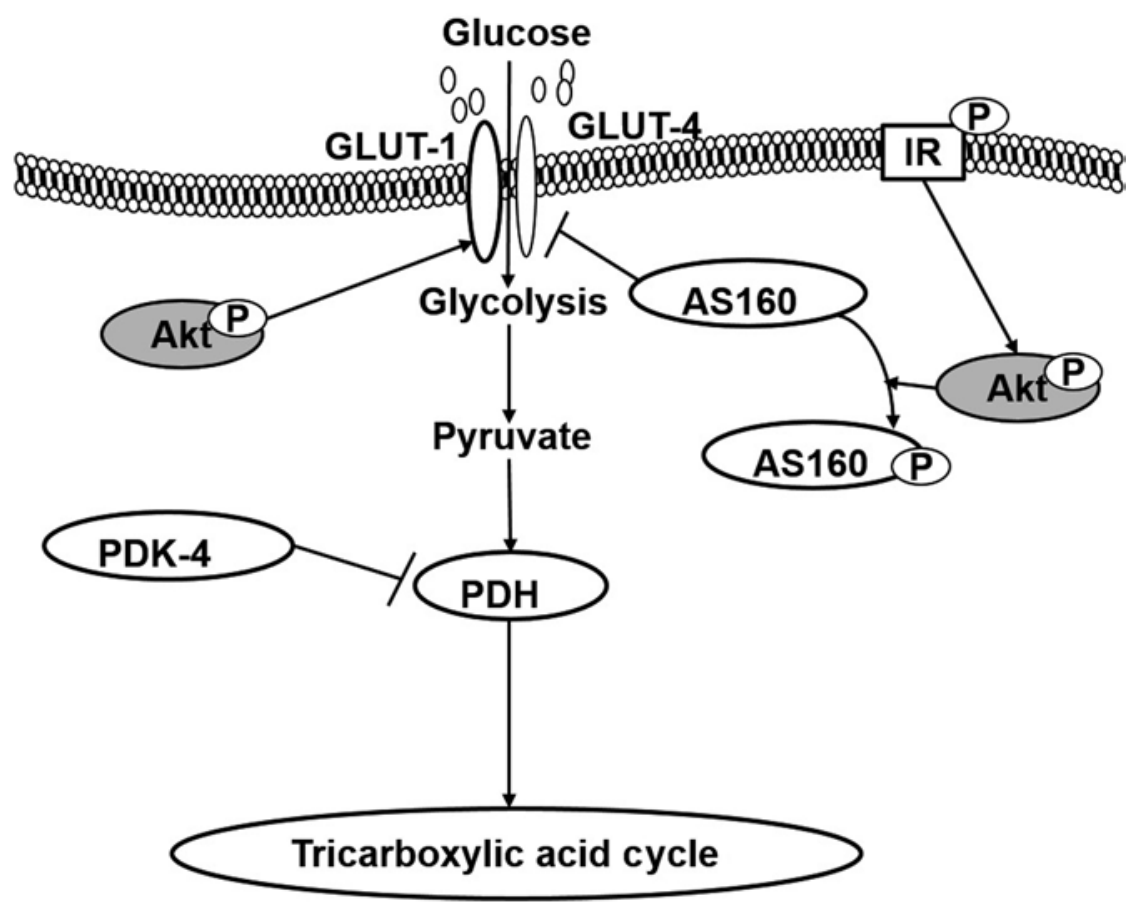

Figure 4

Myocardial uptake of glucose via facilitated diffusion is mediated by glucose transporters located on the sarcolemma. Akt activation results in the translocation of GLUT- 1 and GLUT- 4 to the sarcolemma for the transport of glucose into cardiomyocytes (Sano et al. 2003, Manning \& Cantley 2007). 
Nascimben et al. 2004), there is a reversion to the fetal phenotype of glucose metabolism in postnatal life. This has been attributed to a decrease in the expression of proteins involved in fatty acid uptake (Binas et al. 1999, Hajri et al. 2001). Akt has been shown to play an important role in mediating this shift toward increased glucose metabolism. For example, chronic activation of Akt in transgenic mice increased basal glucose uptake and cardiac glycogen deposition (Matsui et al. 2006). Downregulation of peroxisome proliferator-activated receptor (PPAR) $\alpha$ and PPAR $\gamma$ coactivator 1 (PGC-1) was also reported in transgenic mice with cardiac-specific expression of constitutively activated Akt (Cook et al. 2002). In the hearts of IUGR sheep fetuses, there was increased glucose uptake and metabolic response to insulin to maintain myocardial energy supply and subsequent myocardial function and growth (Barry et al. 2016). There is also increased IR, GLUT-1 and phosphoAkt abundance in the hearts of low-birth-weight lambs at day 21, all of which suggest increased reliance on glucose metabolism for cardiac function (Wang et al. 2013). In addition, in the low-birth-weight lamb, there was increased pyruvate dehydrogenase kinase-4 (PDK-4) abundance, which may indicate impaired pyruvate conversion and decreased ATP production from glucose as a result of inhibiting pyruvate dehydrogenase (PDH) (Wang et al. 2013). In the context of low birth weight, if a switch to the fetal metabolic phenotype in the heart does occur after birth and is permanent, this may be one mechanism leading to increased vulnerability to developing cardiovascular diseases in adult life in individual born low birth weight.

\section{Conclusion}

miR can regulate Akt activation or function as downstream effectors of Akt (Sayed \& Abdellatif 2010), and this has an important role in cardiomyocyte development, with direct consequences for cardiac hypertrophy in response to chronic hypoxemia in the fetus. Although Akt is a target for 'programming', directly blocking Akt is not an ideal therapeutic approach (Buss et al. 2012), because Akt is central to multiple signaling pathways that control homeostasis, including survival, energy production, contractility and response to pathological stress in the heart (Sussman et al. 2011). However, investigating cardiac miRs that can be regulate Akt in the context of low birth weight, may lead to new therapeutic agents to modulate Akt signaling in response to chronic hypoxemia. This may allow reversal of the negative effects of this in utero environment before or shortly after birth. Importantly, the differential effects of cardiac IGF-2R and the effect of Akt on downstream pathways under conditions of decreased substrate supply in utero warrants further investigation. This new knowledge about the development of cardiac hypertrophy in the IUGR and chronically hypoxemic fetus will lead to improved identification and intervention strategies for individuals at risk of cardiovascular disease in later life and have direct significance for global heart health.

\section{Declaration of interest}

The authors declare that there is no conflict of interest that could be perceived as prejudicing the impartiality of this review.

\section{Funding}

K C W W was funded by an NHMRC Early Career Fellowship (APP1090888). J L M was funded by an NHMRC Career Development Fellowship (APP1066916).

\section{References}

Bae S, Xiao Y, Li G, Casiano C \& Zhang L 2003 Effect of maternal chronic hypoxic exposure during gestation on apoptosis in fetal rat heart. American Journal of Physiology: Heart and Circulatory Physiology 285 H983-H990. (doi:10.1152/ajpheart.00005.2003)

Barker DJ, Winter PD, Osmond C, Margetts B \& Simmonds SJ 1989 Weight in infancy and death from ischaemic heart disease. Lancet 2 577-580. (doi:10.1016/S0140-6736(89)90710-1)

Barry JS, Rozance PJ, Brown LD, Anthony RV, Thornburg KL \& Hay WW Jr 2016 Increased fetal myocardial sensitivity to insulin-stimulated glucose metabolism during ovine fetal growth restriction. Experimental Biology and Medicine 241 839-847. (doi:10.1177/1535370216632621)

Bartel DP 2004 MicroRNAs: genomics, biogenesis, mechanism, and function. Cell 116 281-297. (doi:10.1016/S0092-8674(04)00045-5)

Bergmann O, Bhardwaj RD, Bernard S, Zdunek S, Barnabé-Heider F, Walsh S, Zupicich J, Alkass K, Buchholz BA, Druid H, et al. 2009 Evidence for cardiomyocyte renewal in humans. Science 324 98-102. (doi:10.1126/science.1164680)

Bergmann O, Zdunek S, Felker A, Salehpour M, Alkass K, Bernard S, Sjostrom SL, Szewczykowska M, Jackowska T, Dos Remedios C, et al. 2015 Dynamics of cell generation and turnover in the human heart. Cell 161 1566-1575. (doi:10.1016/j.cell.2015.05.026)

Binas B, Danneberg H, McWhir J, Mullins L \& Clark AJ 1999 Requirement for the heart-type fatty acid binding protein in cardiac fatty acid utilization. FASEB Journal 13 805-812.

Black MJ, Siebel AL, Gezmish O, Moritz KM \& Wlodek ME 2012 Normal lactational environment restores cardiomyocyte number after uteroplacental insufficiency: implications for the preterm neonate. American Journal of Physiology: Regulatory, Integrative and Comparative Physiology 302 R1101-R1110. (doi:10.1152/ajpregu.00030.2012)

Botting KJ, Wang KC, Padhee M, McMillen IC, Summers-Pearce B, Rattanatray L, Cutri N, Posterino GS, Brooks DA \& Morrison JL 2012 Early origins of heart disease: low birth weight and determinants of cardiomyocyte endowment. Clinical and Experimental Pharmacology and Physiology 39 814-823. (doi:10.1111/j.1440-1681.2011.05649.x)
๑) 2017 Society for Endocrinology Printed in Great Britain 
Botting KJ, McMillen IC, Forbes H, Nyengaard JR \& Morrison JL 2014 Chronic hypoxemia in late gestation decreases cardiomyocyte number but does not change expression of hypoxia-responsive genes. Journal of the American Heart Association 3 e000531. (doi:10.1161/ JAHA.113.000531)

Bouquet F, Ousset M, Biard D, Fallone F, Dauvillier S, Frit P, Salles B \& Muller C 2011 A DNA-dependent stress response involving DNA-PK occurs in hypoxic cells and contributes to cellular adaptation to hypoxia. Journal of Cell Science 124 1943-1951. (doi:10.1242/jcs.078030)

Branco MR, Oda M \& Reik W 2008 Safeguarding parental identity: Dnmt1 maintains imprints during epigenetic reprogramming in early embryogenesis. Genes and Development 22 1567-1571. (doi:10.1101/ gad.1690508)

Brunet A, Bonni A, Zigmond MJ, Lin MZ, Juo P, Hu LS, Anderson MJ, Arden KC, Blenis J \& Greenberg ME 1999 Akt promotes cell survival by phosphorylating and inhibiting a Forkhead transcription factor. Cell 96 857-868. (doi:10.1016/S0092-8674(00)80595-4)

Burrell JH, Boyn AM, Kumarasamy V, Hsieh A, Head SI \& Lumbers ER 2003 Growth and maturation of cardiac myocytes in fetal sheep in the second half of gestation. Anatomical Record: Part A, Discoveries in Molecular, Cellular, and Evolutionary Biology 274 952-961. (doi:10.1002/ar.a.10110)

Buss SJ, Riffel JH, Malekar P, Hagenmueller M, Asel C, Zhang M, Weiss C, Katus HA \& Hardt SE 2012 Chronic Akt blockade aggravates pathological hypertrophy and inhibits physiological hypertrophy. American Journal of Physiology: Heart and Circulatory Physiology $\mathbf{3 0 2}$ H420-H430. (doi:10.1152/ajpheart.00211.2011)

Cardone MH, Roy N, Stennicke HR, Salvesen GS, Franke TF, Stanbridge E, Frisch S \& Reed JC 1998 Regulation of cell death protease caspase-9 by phosphorylation. Science 282 1318-1321. (doi:10.1126/ science.282.5392.1318)

Chan LL, Sebert SP, Hyatt MA, Stephenson T, Budge H, Symonds ME \& Gardner DS 2009 Effect of maternal nutrient restriction from early to midgestation on cardiac function and metabolism after adolescentonset obesity. American Journal of Physiology: Regulatory, Integrative and Comparative Physiology 296 R1455-R1463. (doi:10.1152/ ajpregu.91019.2008)

Chang Z, Zhang Q, Feng Q, Xu J, Teng T, Luan Q, Shan C, Hu Y, Hemmings BA, Gao X, et al. 2010 Deletion of Akt1 causes heart defects and abnormal cardiomyocyte proliferation. Developmental Biology 347 384-391. (doi:10.1016/j.ydbio.2010.08.033)

Chu CH, Tzang BS, Chen LM, Kuo CH, Cheng YC, Chen LY, Tsai FJ, Tsai CH, Kuo WW \& Huang CY 2008 IGF-II/mannose-6-phosphate receptor signaling induced cell hypertrophy and atrial natriuretic peptide/BNP expression via Gaq interaction and protein kinase $\mathrm{C}-\alpha / \mathrm{CaMKII}$ activation in $\mathrm{H} 9 \mathrm{c} 2$ cardiomyoblast cells. Journal of Endocrinology 197 381-390. (doi:10.1677/JOE-07-0619)

Chu CH, Lo JF, Hu WS, Lu RB, Chang MH, Tsai FJ, Tsai CH, Weng YS, Tzang BS \& Huang CY 2012 Histone acetylation is essential for ANGII-induced IGF-IIR gene expression in H9c2 cardiomyoblast cells and pathologically hypertensive rat heart. Journal of Cellular Physiology 227 259-268. (doi:10.1002/jcp.22728)

Cook SA, Matsui T, Li L \& Rosenzweig A 2002 Transcriptional effects of chronic Akt activation in the heart. Journal of Biological Chemistry $\mathbf{2 7 7}$ 22528-22533. (doi:10.1074/jbc.M201462200)

Datta SR, Dudek H, Tao X, Masters S, Fu H, Gotoh Y \& Greenberg ME 1997 Akt phosphorylation of BAD couples survival signals to the cell-intrinsic death machinery. Cell 91 231-241. (doi:10.1016/S00928674(00)80405-5)

DeBosch B, Treskov I, Lupu TS, Weinheimer C, Kovacs A, Courtois M \& Muslin AJ 2006 Akt1 is required for physiological cardiac growth. Circulation 113 2097-2104. (doi:10.1161/ CIRCULATIONAHA.105.595231)

del Peso L, Gonzalez-Garcia M, Page C, Herrera R \& Nunez G 1997 Interleukin-3-induced phosphorylation of $\mathrm{BAD}$ through the protein kinase Akt. Science $\mathbf{2 7 8}$ 687-689. (doi:10.1126/science.278.5338.687)
Dey N, Ghosh-Choudhury N, Kasinath BS \& Choudhury GG 2012 TGF $\beta$-stimulated microRNA-21 utilizes PTEN to orchestrate AKT/mTORC1 signaling for mesangial cell hypertrophy and matrix expansion. PLOS ONE 7 e42316. (doi:10.1371/journal. pone.0042316)

Dolinoy DC, Weidman JR \& Jirtle RL 2007 Epigenetic gene regulation: linking early developmental environment to adult disease. Reproductive Toxicology 23 297-307. (doi:10.1016/j. reprotox.2006.08.012)

Domenighetti AA, Wang Q, Egger M, Richards SM, Pedrazzini T \& Delbridge LM 2005 Angiotensin II-mediated phenotypic cardiomyocyte remodeling leads to age-dependent cardiac dysfunction and failure. Hypertension 46 426-432. (doi:10.1161/01. HYP.0000173069.53699.d9)

Donthi RV, Huisamen B \& Lochner A 2000 Effect of vanadate and insulin on glucose transport in isolated adult rat cardiomyocytes. Cardiovascular Drugs and Therapy 14 463-470. (doi:10.102 3/A:1007876703644)

Eskildsen TV, Schneider M, Sandberg MB, Skov V, Brønnum H, Thomassen M, Kruse TA, Andersen DC \& Sheikh SP 2015 The microRNA-132/212 family fine-tunes multiple targets in Angiotensin II signalling in cardiac fibroblasts. Journal of the Renin-AngiotensinAldosterone System 16 1288-1297. (doi:10.1177/1470320314539367)

Fall CH, Osmond C, Barker DJ, Clark PM, Hales CN, Stirling Y \& Meade TW 1995a Fetal and infant growth and cardiovascular risk factors in women. BMJ 310 428-432. (doi:10.1136/bmj.310.6977.428)

Fall CH, Vijayakumar M, Barker DJ, Osmond C \& Duggleby S 1995b Weight in infancy and prevalence of coronary heart disease in adult life. BMJ 310 17-19. (doi:10.1136/bmj.310.6971.17)

Fernandez-Gonzalez R, Ramirez MA, Pericuesta E, Calle A \& GutierrezAdan A 2010 Histone modifications at the blastocyst Axin1(Fu) locus mark the heritability of in vitro culture-induced epigenetic alterations in mice. Biology of Reproduction 83 720-727. (doi:10.1095/ biolreprod.110.084715)

Foley NH, Bray IM, Tivnan A, Bryan K, Murphy DM, Buckley PG Ryan J, O'Meara A, O'Sullivan M \& Stallings RL 2010 MicroRNA-184 inhibits neuroblastoma cell survival through targeting the serine/ threonine kinase AKT2. Molecular Cancer 9 83. (doi:10.1186/14764598-9-83)

Fornari F, Milazzo M, Chieco P, Negrini M, Marasco E, Capranico G, Mantovani V, Marinello J, Sabbioni S, Callegari E, et al. 2012 In hepatocellular carcinoma miR-519d is up-regulated by p53 and DNA hypomethylation and targets CDKN1A/p21, PTEN, AKT3 and TIMP2. Journal of Pathology 227 275-285. (doi:10.1002/path.3995)

Fratz S, Hager A, Schreiber C, Schwaiger M, Hess J \& Stern HC 2011 Long-term myocardial scarring after operation for anomalous left coronary artery from the pulmonary artery. Annals of Thoracic Surgery 92 1761-1765. (doi:10.1016/j.athoracsur.2011.06.021)

Friehs I, Barillas R, Vasilyev NV, Roy N, McGowan FX \& del Nido PJ 2006 Vascular endothelial growth factor prevents apoptosis and preserves contractile function in hypertrophied infant heart. Circulation 114 I290-I295. (doi:10.1161/circulationaha.105.001289)

Gao S, Wassler M, Zhang L, Li Y, Wang J, Zhang Y, Shelat H, Williams J \& Geng YJ 2014 MicroRNA-133a regulates insulin-like growth factor-1 receptor expression and vascular smooth muscle cell proliferation in murine atherosclerosis. Atherosclerosis 232 171-179. (doi:10.1016/j. atherosclerosis.2013.11.029)

Garofalo M, Di Leva G, Romano G, Nuovo G, Suh SS, Ngankeu A, Taccioli C, Pichiorri F, Alder H, Secchiero P, et al. 2009 miR-221\&222 regulate TRAIL resistance and enhance tumorigenicity through PTEN and TIMP3 downregulation. Cancer Cell 16 498-509. (doi:10.1016/j. ccr.2009.10.014)

Grandjean V, O’Neill L, Sado T, Turner B \& Ferguson-Smith A 2001 Relationship between DNA methylation, histone $\mathrm{H} 4$ acetylation and gene expression in the mouse imprinted Igf2-H19 domain. FEBS Letters 488 165-169. (doi:10.1016/S0014-5793(00)02349-8) 
Guo R, Chen J, Mitchell DL \& Johnson DG 2011 GCN5 and E2F1 stimulate nucleotide excision repair by promoting H3K9 acetylation at sites of damage. Nucleic Acids Research 39 1390-1397. (doi:10.1093/ nar/gkq983)

Hajri T, Ibrahimi A, Coburn CT, Knapp FF Jr, Kurtz T, Pravenec M \& Abumrad NA 2001 Defective fatty acid uptake in the spontaneously hypertensive rat is a primary determinant of altered glucose metabolism, hyperinsulinemia, and myocardial hypertrophy. Journal of Biological Chemistry 276 23661-23666. (doi:10.1074/jbc. M100942200)

Hanson MA \& Skinner MK 2016 Developmental origins of epigenetic transgenerational inheritance. Environmental Epigenetics 2 dvw002. (doi:10.1093/eep/dvw002)

Hauton D \& Ousley V 2009 Prenatal hypoxia induces increased cardiac contractility on a background of decreased capillary density. BMC Cardiovascular Disorders 9 1. (doi:10.1186/1471-2261-9-1)

Horton JL, Martin OJ, Lai L, Riley NM, Richards AL, Vega RB, Leone TC, Pagliarini DJ, Muoio DM, Bedi KC Jr, et al. 2016 Mitochondrial protein hyperacetylation in the failing heart. JCI Insight $\mathbf{1}$ e84897. (doi:10.1172/jci.insight.84897)

Hu JF, Pham J, Dey I, Li T, Vu TH \& Hoffman AR 2000 Allele-specific histone acetylation accompanies genomic imprinting of the insulinlike growth factor II receptor gene. Endocrinology 141 4428-4435. (doi:10.1210/en.141.12.4428)

Hua Y, Zhang Y, Ceylan-Isik AF, Wold LE, Nunn JM \& Ren J 2011 Chronic Akt activation accentuates aging-induced cardiac hypertrophy and myocardial contractile dysfunction: role of autophagy. Basic Research in Cardiology 106 1173-1191. (doi:10.1007/s00395-011-0222-8)

Huang M-B, Xu H, Xie S-J, Zhou H \& Qu L-H 2011 Insulin-like growth factor-1 receptor Is regulated by microRNA-133 during skeletal myogenesis. PLoS ONE 6 e29173. (doi:10.1371/journal.pone.0029173)

Huxley R, Owen CG, Whincup PH, Cook DG, Rich-Edwards J, Smith GD \& Collins R 2007 Is birth weight a risk factor for ischemic heart disease in later life? American Journal of Clinical Nutrition $\mathbf{8 5}$ 1244-1250.

Ichihara S, Senbonmatsu T, Price E Jr, Ichiki T, Gaffney FA \& Inagami T 2001 Angiotensin II type 2 receptor is essential for left ventricular hypertrophy and cardiac fibrosis in chronic angiotensin II-induced hypertension. Circulation 104 346-351. (doi:10.1161/01. CIR.104.3.346)

Iemitsu M, Miyauchi T, Maeda S, Sakai S, Fujii N, Miyazaki H, Kakinuma Y, Matsuda M \& Yamaguchi I 2003 Cardiac hypertrophy by hypertension and exercise training exhibits different gene expression of enzymes in energy metabolism. Hypertension Research 26 829-837. (doi:10.1291/hypres.26.829)

Ikeda S, Kong SW, Lu J, Bisping E, Zhang H, Allen PD, Golub TR, Pieske B \& Pu WT 2007 Altered microRNA expression in human heart disease. Physiological Genomics 31 367-373. (doi:10.1152/ physiolgenomics.00144.2007)

Jeppesen P 1997 Histone acetylation: a possible mechanism for the inheritance of cell memory at mitosis. Bioessays 19 67-74. (doi:10.1002/bies.950190111)

Jeppesen PL, Christensen GL, Schneider M, Nossent AY, Jensen HB, Andersen DC, Eskildsen T, Gammeltoft S, Hansen JL \& Sheikh SP 2011 Angiotensin II type 1 receptor signalling regulates microRNA differentially in cardiac fibroblasts and myocytes. British Journal of Pharmacology 164 394-404. (doi:10.1111/j.1476-5381.2011.01375.x)

Jin Q, Yu LR, Wang L, Zhang Z, Kasper LH, Lee JE, Wang C, Brindle PK, Dent SY \& Ge K 2011 Distinct roles of GCN5/PCAF-mediated H3K9ac and CBP/p300-mediated H3K18/27ac in nuclear receptor transactivation. EMBO Journal 30 249-262. (doi:10.1038/ emboj.2010.318)

Johnson AB, Denko N \& Barton MC 2008 Hypoxia induces a novel signature of chromatin modifications and global repression of transcription. Mutation Research 640 174-179. (doi:10.1016/j. mrfmmm.2008.01.001)
Jonker SS \& Louey S 2016 Endocrine and other physiologic modulators of perinatal cardiomyocyte endowment. Journal of Endocrinology $\mathbf{2 2 8}$ R1-R18. (doi:10.1530/JOE-15-0309)

Jonker SS, Faber JJ, Anderson DF, Thornburg KL, Louey S \& Giraud GD $2007 a$ Sequential growth of fetal sheep cardiac myocytes in response to simultaneous arterial and venous hypertension. American Journal of Physiology: Regulatory, Integrative and Comparative Physiology 292 R913-R919. (doi:10.1152/ajpregu.00484.2006)

Jonker SS, Zhang L, Louey S, Giraud GD, Thornburg KL \& Faber JJ 2007b Myocyte enlargement, differentiation, and proliferation kinetics in the fetal sheep heart. Journal of Applied Physiology 102 1130-1142. (doi:10.1152/japplphysiol.00937.2006)

Kato M, Putta S, Wang M, Yuan H, Lanting L, Nair I, Gunn A, Nakagawa Y, Shimano H, Todorov I, et al. 2009 TGF-beta activates Akt kinase through a microRNA-dependent amplifying circuit targeting PTEN. Nature Cell Biology 11 881-889. (doi:10.1038/ncb1897)

Kiefer JC 2007 Epigenetics in development. Developmental Dynamics 236 1144-1156. (doi:10.1002/dvdy.21094)

Knezevic I, Patel A, Sundaresan NR, Gupta MP, Solaro RJ, Nagalingam RS \& Gupta M 2012 A novel cardiomyocyte-enriched microRNA, miR-378, targets insulin-like growth factor 1 receptor: implications in postnatal cardiac remodeling and cell survival. Journal of Biological Chemistry 287 12913-12926. (doi:10.1074/jbc. M111.331751)

Kornfeld S 1992 Structure and function of the mannose 6-phosphate/ insulinlike growth factor II receptors. Annual Review of Biochemistry 61 307-330. (doi:10.1146/annurev.bi.61.070192.001515)

Kumarswamy R, Lyon AR, Volkmann I, Mills AM, Bretthauer J, Pahuja A Geers-Knörr C, Kraft T, Hajjar RJ, Macleod KT, et al. 2012a SERCA2a gene therapy restores microRNA-1 expression in heart failure via an Akt/FoxO3A-dependent pathway. European Heart Journal 33 1067-1075. (doi:10.1093/eurheartj/ehs043)

Kumarswamy R, Volkmann I, Jazbutyte V, Dangwal S, Park DH \& Thum T $2012 b$ Transforming growth factor- $\beta$-induced endothelialto-mesenchymal transition is partly mediated by microRNA- 21 . Arteriosclerosis, Thrombosis, and Vascular Biology 32 361-369. (doi:10.1161/ATVBAHA.111.234286)

Kuo MH, Brownell JE, Sobel RE, Ranalli TA, Cook RG, Edmondson DG, Roth SY \& Allis CD 1996 Transcription-linked acetylation by Gcn5p of histones H3 and H4 at specific lysines. Nature 383 269-272. (doi:10.1038/383269a0)

Langdown ML, Holness MJ \& Sugden MC 2001 Early growth retardation induced by excessive exposure to glucocorticoids in utero selectively increases cardiac GLUT1 protein expression and Akt/protein kinase B activity in adulthood. Journal of Endocrinology 169 11-22. (doi:10.1677/joe.0.1690011)

Leon DA, Lithell HO, Vagero D, Koupilova I, Mohsen R, Berglund L, Lithell UB \& Mckeigue PM 1998 Reduced fetal growth rate and increased risk of death from ischaemic heart disease: cohort study of 15,000 Swedish men and women born 1915-29. BMJ 317 241-245. (doi:10.1136/bmj.317.7153.241)

Levy D, Anderson KM, Savage DD, Kannel WB, Christiansen JC \& Castelli WP 1988 Echocardiographically detected left ventricular hypertrophy: prevalence and risk factors. The Framingham Heart Study. Annals of Internal Medicine 108 7-13. (doi:10.7326/0003-4819. 108-1-7)

Levy D, Garrison RJ, Savage DD, Kannel WB \& Castelli WP 1989 Left ventricular mass and incidence of coronary heart disease in an elderly cohort. The Framingham Heart Study. Annals of Internal Medicine 110 101-107. (doi:10.7326/0003-4819-110-2-101)

Levy D, Garrison RJ, Savage DD, Kannel WB \& Castelli WP 1990 Prognostic implications of echocardiographically determined left ventricular mass in the Framingham Heart Study. New England Journal of Medicine 322 1561-1566. (doi:10.1056/NEJM199005313222203)

Li F, Wang X, Bunger PC \& Gerdes AM 1997a Formation of binucleated cardiac myocytes in rat heart: I. Role of actin-myosin contractile 
ring. Journal of Molecular and Cellular Cardiology 29 1541-1551. (doi:10.1006/jmcc.1997.0381)

Li F, Wang X \& Gerdes AM 1997b Formation of binucleated cardiac myocytes in rat heart: II. Cytoskeletal organisation. Journal of Molecular and Cellular Cardiology 29 1553-1565. (doi:10.1006/ jmcc.1997.0403)

Li G, Xiao Y, Estrella J, Ducsay C, Gilbert R \& Zhang L 2003 Effect of fetal hypoxia on heart susceptibility to ischemia and reperfusion injury in the adult rat. Journal of the Society for Gynecologic Investigation $\mathbf{1 0}$ 265-274. (doi:10.1016/S1071-5576(03)00074-1)

Lin RJ, Lin YC \& Yu AL 2010 miR-149* induces apoptosis by inhibiting Akt1 and E2F1 in human cancer cells. Molecular Carcinogenesis 49 719-727.

Lopaschuk GD, Spafford MA \& Marsh DR 1991 Glycolysis is predominant source of myocardial ATP production immediately after birth. American Journal of Physiology: Heart and Circulatory Physiology 261 H1698-H1705.

Lopaschuk GD, Ussher JR, Folmes CD, Jaswal JS \& Stanley WC 2010 Myocardial fatty acid metabolism in health and disease. Physiological Reviews 90 207-258. (doi:10.1152/physrev.00015.2009)

Lumbers ER, Boyce AC, Joulianos G, Kumarasamy V, Barner E, Segar JL \& Burrell JH 2005 Effects of cortisol on cardiac myocytes and on expression of cardiac genes in fetal sheep. American Journal of Physiology: Regulatory, Integrative and Comparative Physiology $\mathbf{2 8 8}$ R567-R574. (doi:10.1152/ajpregu.00556.2004)

Lumbers ER, Kim MY, Burrell JH, Kumarasamy V, Boyce AC, Gibson KJ, Gatford KL \& Owens JA 2009 Effects of intrafetal IGF-I on growth of cardiac myocytes in late-gestation fetal sheep. American Journal of Physiology: Endocrinology and Metabolism 296 E513-E519. (doi:10.1152/ajpendo.90497.2008)

Maeng YS, Choi HJ, Kwon JY, Park YW, Choi KS, Min JK, Kim YH, Suh PG, Kang KS, Won MH, et al. 2009 Endothelial progenitor cell homing: prominent role of the IGF2-IGF2R-PLCbeta2 axis. Blood 113 233-243. (doi:10.1182/blood-2008-06-162891)

Manning B \& Cantley L 2007 AKT/PKB signaling: navigating downstream. Cell 129 1261-1274. (doi:10.1016/j.cell.2007.06.009)

Master JS, Zimanyi MA, Yin KV, Moritz KM, Gallo LA, Tran M, Wlodek ME \& Black MJ 2014 Transgenerational left ventricular hypertrophy and hypertension in offspring after uteroplacental insufficiency in male rats. Clinical and Experimental Pharmacology and Physiology 41 884-890. (doi:10.1111/1440-1681.12303)

Mathers JC, Strathdee G \& Relton CL 2010 Induction of epigenetic alterations by dietary and other environmental factors. Advances in Genetics 71 3-39. (doi:10.1016/b978-0-12-380864-6.00001-8)

Matsui T, Nagoshi T, Hong E, Luptak I, Hartil K, Li L, Gorovits N, Charron M, Kim J, Tian R, et al. 2006 Effects of chronic Akt activation on glucose uptake in the heart. American Journal of Physiology: Endocrinology and Metabolism 290 E789-E797. (doi:10.1152/ ajpendo.00564.2004)

McMullen JR, Sherwood MC, Tarnavski O, Zhang L, Dorfman AL, Shioi T \& Izumo S 2004 Inhibition of mTOR signaling with rapamycin regresses established cardiac hypertrophy induced by pressure overload. Circulation 109 3050-3055. (doi:10.1161/01. CIR.0000130641.08705.45)

Mimura I, Tanaka T, Wada Y, Kodama T \& Nangaku M 2011 Pathophysiological response to hypoxia - from the molecular mechanisms of malady to drug discovery: epigenetic regulation of the hypoxic response via hypoxia-inducible factor and histone modifying enzymes. Journal of Pharmacological Sciences 115 453-458. (doi:10.1254/jphs.10R19FM)

Mollova M, Bersell K, Walsh S, Savla J, Das LT, Park SY, Silberstein LE, Dos Remedios CG, Graham D, Colan S, et al. 2013 Cardiomyocyte proliferation contributes to heart growth in young humans. PNAS 110 1446-1451. (doi:10.1073/pnas.1214608110)

Morrison JL, Botting KJ, Dyer JL, Williams SJ, Thornburg KL \& McMillen IC 2007 Restriction of placental function alters heart development in the sheep fetus. American Journal of Physiology: Regulatory, Integrative and Comparative Physiology 293 R306-R313. (doi:10.1152/ajpregu.00798.2006)

Morrison JL, Zhang S, Tellam RL, Brooks DA, McMillen IC, Porrello ER \& Botting KJ 2015 Regulation of microRNA during cardiomyocyte maturation in sheep. BMC Genomics 16 541. (doi:10.1186/s12864015-1693-z)

Mutharasan RK, Nagpal V, Ichikawa Y \& Ardehali H 2011 microRNA-210 is upregulated in hypoxic cardiomyocytes through Akt- and p53-dependent pathways and exerts cytoprotective effects. American Journal of Physiology: Heart and Circulatory Physiology $\mathbf{3 0 1}$ H1519-H1530. (doi:10.1152/ajpheart.01080.2010)

Nascimben L, Ingwall JS, Lorell BH, Pinz I, Schultz V, Tornheim K \& Tian R 2004 Mechanisms for increased glycolysis in the hypertrophied rat heart. Hypertension 44 662-667. (doi:10.1161/01. HYP.0000144292.69599.0c)

Ollikainen M, Smith KR, Joo EJ, Ng HK, Andronikos R, Novakovic B, Abdul Aziz NK, Carlin JB, Morley R, Saffery R, et al. 2010 DNA methylation analysis of multiple tissues from newborn twins reveals both genetic and intrauterine components to variation in the human neonatal epigenome. Human Molecular Genetics 19 4176-4188. (doi:10.1093/hmg/ddq336)

Osmond C, Barker DJ, Winter PD, Fall CH \& Simmonds SJ 1993 Early growth and death from cardiovascular disease in women. BMJ $\mathbf{3 0 7}$ 1519-1524. (doi:10.1136/bmj.307.6918.1519)

Palumbo T, Faucz FR, Azevedo M, Xekouki P, Iliopoulos D \& Stratakis CA 2013 Functional screen analysis reveals miR-26b and miR-128 as central regulators of pituitary somatomammotrophic tumor growth through activation of the PTEN-AKT pathway. Oncogene 32 1651-1659. (doi:10.1038/onc.2012.190)

Patterson AJ, Chen M, Xue Q, Xiao D \& Zhang L 2010 Chronic prenatal hypoxia induces epigenetic programming of PKC\{epsilon\} gene repression in rat hearts. Circulation Research 107 365-373. (doi:10.1161/CIRCRESAHA.110.221259)

Porrello ER 2013 microRNAs in cardiac development and regeneration. Clinical Science 125 151-166. (doi:10.1042/CS20130011)

Porrello ER, D'Amore A, Curl CL, Allen AM, Harrap SB, Thomas WG \& Delbridge LM 2009 Angiotensin II type 2 receptor antagonizes angiotensin II type 1 receptor-mediated cardiomyocyte autophagy. Hypertension 53 1032-1040. (doi:10.1161/ HYPERTENSIONAHA.108.128488)

Porrello ER, Johnson BA, Aurora AB, Simpson E, Nam YJ, Matkovich SJ, Dorn GW 2nd, van Rooij E \& Olson EN 2011 MiR-15 family regulates postnatal mitotic arrest of cardiomyocytes. Circulation Research 109 670-679. (doi:10.1161/CIRCRESAHA.111.248880)

Powell K, Rooke JA, McEvoy TG, Ashworth CJ, Robinson JJ, Wilmut I, Young LE \& Sinclair KD 2006 Zygote donor nitrogen metabolism and in vitro embryo culture perturbs in utero development and IGF2R expression in ovine fetal tissues. Theriogenology 66 1901-1912. (doi:10.1016/j.theriogenology.2006.05.008)

Ptak C \& Petronis A 2008 Epigenetics and complex disease: from etiology to new therapeutics. Annual Review of Pharmacology and Toxicology 48 257-276. (doi:10.1146/annurev. pharmtox.48.113006.094731)

Qu C, Liang Z, Huang J, Zhao R, Su C, Wang S, Wang X, Zhang R, Lee MH \& Yang H 2012 MiR-205 determines the radioresistance of human nasopharyngeal carcinoma by directly targeting PTEN. Cell Cycle $\mathbf{1 1}$ 785-796. (doi:10.4161/cc.11.4.19228)

Rane S, He M, Sayed D, Yan L, Vatner D \& Abdellatif M 2010 An antagonism between the AKT and beta-adrenergic signaling pathways mediated through their reciprocal effects on miR-199a-5p. Cellular Signaling 22 1054-1062. (doi:10.1016/j.cellsig.2010.02.008)

Reik W, Constância M, Fowden A, Anderson N, Dean W, FergusonSmith A, Tycko B \& Sibley C 2003 Regulation of supply and demand for maternal nutrients in mammals by imprinted genes. Journal of Physiology 547 135-144. (doi:10.1113/jphysiol.2002.033274) 
Rich-Edwards J, Stampfer MJ, Manson JE, Rosner B, Hankinson SE, Colditz GA, Willett WC \& Hennekens CH 1997 Birth weight and risk of cardiovascular disease in a cohort of women followed up since 1976. BMJ 315 396-400. (doi:10.1136/bmj.315.7105.396)

Saini S, Arora S, Majid S, Shahryari V, Chen Y, Deng G, Yamamura S, Ueno K \& Dahiya R 2011 Curcumin modulates microRNA-203-mediated regulation of the Src-Akt axis in bladder cancer. Cancer Prevention Research 4 1698-1709. (doi:10.1158/1940-6207.CAPR-11-0267)

Sang HQ, Jiang ZM, Zhao QP \& Xin F 2015 MicroRNA-133a improves the cardiac function and fibrosis through inhibiting Akt in heart failure rats. Biomedicine and Pharmacotherapy 71 185-189. (doi:10.1016/j. biopha.2015.02.030)

Sano H, Kane S, Sano E, Mîinea CP, Asara JM, Lane WS, Garner CW \& Lienhard GE 2003 Insulin-stimulated phosphorylation of a Rab GTPase-activating protein regulates GLUT4 translocation. Journal of Biological Chemistry 278 14599-14602. (doi:10.1074/jbc.C300063200)

Saraste A \& Pulkki K 2000 Morphologic and biochemical hallmarks of apoptosis. Cardiovascular Research 45 528-537. (doi:10.1016/S00086363(99)00384-3)

Sayed D \& Abdellatif M 2010 AKT-ing via microRNA. Cell Cycle 9 3213-3217. (doi:10.4161/cc.9.16.12634)

Sayed D, He M, Hong C, Gao S, Rane S, Yang Z \& Abdellatif M 2010 MicroRNA-21 is a downstream effector of AKT that mediates its antiapoptotic effects via suppression of Fas ligand. Journal of Biological Chemistry 285 20281-20290. (doi:10.1074/jbc.M110.109207)

Shiojima I \& Walsh K 2006 Regulation of cardiac growth and coronary angiogenesis by the Akt/PKB signaling pathway. Genes and Development 20 3347-3365. (doi:10.1101/gad.1492806)

Shiojima I, Sato K, Izumiya Y, Schiekofer S, Ito M, Liao R, Colucci WS \& Walsh K 2005 Disruption of coordinated cardiac hypertrophy and angiogenesis contributes to the transition to heart failure. Journal of Clinical Investigation 115 2108-2118. (doi:10.1172/JCI24682)

Singh P, Cho J, Tsai SY, Rivas GE, Larson GP \& Szabo PE 2010 Coordinated allele-specific histone acetylation at the differentially methylated regions of imprinted genes. Nucleic Acids Research $\mathbf{3 8}$ 7974-7990. (doi:10.1093/nar/gkq680)

Small EM, O’Rourke JR, Moresi V, Sutherland LB, McAnally J, Gerard RD, Richardson JA \& Olson EN 2010 Regulation of PI3-kinase/Akt signaling by muscle-enriched microRNA-486. PNAS 107 4218-4223. (doi:10.1073/pnas.1000300107)

Smith CM, Haimberger ZW, Johnson CO, Wolf AJ, Gafken PR, Zhang Z, Parthun MR \& Gottschling DE 2002 Heritable chromatin structure: mapping 'memory' in histones H3 and H4. PNAS 99 16454-16461. (doi:10.1073/pnas.182424999)

Smolich JJ, Walker AM, Campbell GR \& Adamson TM 1989 Left and right ventricular myocardial morphometry in fetal, neonatal, and adult sheep. American Journal of Physiology 257 H1-H9.

Stacy V, De Matteo R, Brew N, Sozo F, Probyn ME, Harding R \& Black MJ 2009 The influence of naturally occurring differences in birthweight on ventricular cardiomyocyte number in sheep. Anatomical Record 292 29-37. (doi:10.1002/ar.20789)

Sun L, Zhao H, Xu Z, Liu Q, Liang Y, Wang L, Cai X, Zhang L, Hu L, Wang G, et al. 2007 Phosphatidylinositol 3-kinase/protein kinase B pathway stabilizes DNA methyltransferase I protein and maintains DNA methylation. Cellular Signaling 19 2255-2263. (doi:10.1016/j. cellsig.2007.06.014)

Sundgren NC, Giraud GD, Schultz JM, Lasarev MR, Stork PJ \& Thornburg KL 2003 Extracellular signal-regulated kinase and phosphoinositol-3 kinase mediate IGF-1 induced proliferation of fetal sheep cardiomyocytes. American Journal of Physiology: Regulatory, Integrative and Comparative Physiology 285 R1481-R1489. (doi:10.1152/ajpregu.00232.2003)

Sussman MA, Völkers M, Fischer K, Bailey B, Cottage CT, Din S, Gude N, Avitabile D, Alvarez R, Sundararaman B, et al. 2011 Myocardial AKT: the omnipresent nexus. Physiological Reviews 91 1023-1070. (doi:10.1152/physrev.00024.2010)
Tappia PS, Nijjar MS, Mahay A, Aroutiounova N \& Dhalla NS 2005 Phospholipid profile of developing heart of rats exposed to low-protein diet in pregnancy. American Journal of Physiology: Regulatory, Integrative and Comparative Physiology 289 R1400-R1406. (doi:10.1152/ajpregu.00319.2005)

Tatsuguchi M, Seok HY, Callis TE, Thomson JM, Chen JF, Newman M, Rojas M, Hammond SM \& Wang DZ 2007 Expression of microRNAs is dynamically regulated during cardiomyocyte hypertrophy. Journal of Molecular and Cellular Cardiology 42 1137-1141. (doi:10.1016/j. yjmcc.2007.04.004)

Thompson LP \& Al-Hasan Y 2012 Impact of oxidative stress in fetal programming. Journal of Pregnancy 2012 article ID 582748. (doi:10.1155/2012/582748)

Thornburg KL, Louey S \& Giraud GD 2008 The role of growth in heart development. Nestlé Nutrition Institute Workshop Series: Pediatric Program 61 39-51. (doi:10.1159/000113169)

Thum T, Galuppo P, Wolf C, Fiedler J, Kneitz S, van Laake LW, Doevendans PA, Mummery CL, Borlak J, Haverich A, et al. 2007 MicroRNAs in the human heart. A clue to fetal gene reprogramming in heart failure. Circulation 116 258-267. (doi:10.1161/ CIRCULATIONAHA.107.687947)

Tosh DN, Fu Q, Callaway CW, McKnight RA, McMillen IC, Ross MG, Lane RH \& Desai M 2010 Epigenetics of programmed obesity: alteration in IUGR rat hepatic IGF1 mRNA expression and histone structure in rapid vs. delayed postnatal catch-up growth. American Journal of Physiology: Gastrointestinal and Liver Physiology 299 G1023-G1029. (doi:10.1152/ajpgi.00052.2010)

Turner CL, Mackay DM, Callaway JL, Docherty LE, Poole RL, Bullman H, Lever M, Castle BM, Kivuva EC, Turnpenny PD, et al. 2010 Methylation analysis of 79 patients with growth restriction reveals novel patterns of methylation change at imprinted loci. European Journal of Human Genetics 18 648-655. (doi:10.1038/ ejhg.2009.246)

van Heerde WL, Robert-Offerman S, Dumont E, Hofstra L, Doevendans PA, Smits JF, Daemen MJ \& Reutelingsperger CP 2000 Markers of apoptosis in cardiovascular tissues: focus on Annexin V. Cardiovascular Research 45 549-559. (doi:10.1016/S00086363(99)00396-X)

Veille JC, Hanson R, Sivakoff M, Hoen H \& Ben-Ami M 1993 Fetal cardiac size in normal, intrauterine growth retarded, and diabetic pregnancies. American Journal of Perinatology 10 275-279. (doi:10.1055/s-2007-994739)

VerMilyea MD, O’Neill LP \& Turner BM 2009 Transcription-independent heritability of induced histone modifications in the mouse preimplantation embryo. PLoS ONE 4 e6086. (doi:10.1371/journal. pone.0006086)

Vijayakumar M, Fall CH, Osmond C \& Barker DJ 1995 Birth weight, weight at one year, and left ventricular mass in adult life. British Heart Journal 73 363-367. (doi:10.1136/hrt.73.4.363)

Vu TH, Li T \& Hoffman AR 2004 Promoter-restricted histone code, not the differentially methylated DNA regions or antisense transcripts, marks the imprinting status of IGF2R in human and mouse. Human Molecular Genetics 13 2233-2245. (doi:10.1093/hmg/ddh244)

Wang X, Zhang X, Ren XP, Chen J, Liu H, Yang J, Medvedovic M, Hu Z \& Fan GC 2010 MicroRNA-494 targeting both proapoptotic and antiapoptotic proteins protects against ischemia/reperfusioninduced cardiac injury. Circulation 122 1308-1318. (doi:10.1161/ CIRCULATIONAHA.110.964684)

Wang KC, Zhang L, McMillen IC, Botting KJ, Duffield JA, Zhang S, Suter CM, Brooks DA \& Morrison JL 2011 Fetal growth restriction and the programming of heart growth and cardiac insulin-like growth factor 2 expression in the lamb. Journal of Physiology $5894709-4722$. (doi:10.1113/jphysiol.2011.211185)

Wang KC, Brooks DA, Botting KJ \& Morrison JL 2012a IGF-2R-mediated signaling results in hypertrophy of cultured cardiomyocytes from fetal sheep. Biology of Reproduction 86183. 
Wang KC, Brooks DA, Thornburg KL \& Morrison JL 2012b Activation of IGF-2R stimulates cardiomyocyte hypertrophy in the late gestation sheep fetus. Journal of Physiology 590 5425-5437. (doi:10.1113/ jphysiol.2012.238410)

Wang KC, Lim CH, McMillen IC, Duffield JA, Brooks DA \& Morrison JL 2013 Alteration of cardiac glucose metabolism in association to low birth weight: experimental evidence in lambs with left ventricular hypertrophy. Metabolism 62 1662-1672. (doi:10.1016/j. metabol.2013.06.013)

Wang B, Sun F, Dong N, Sun Z, Diao Y, Zheng C, Sun J, Yang Y \& Jiang D 2014 MicroRNA-7 directly targets insulin-like growth factor 1 receptor to inhibit cellular growth and glucose metabolism in gliomas. Diagnostic Pathology 19 211. (doi:10.1186/s13000-014-0211-y)

Wang KC, Brooks DA, Summers-Pearce B, Bobrovskaya L, Tosh DN, Duffield JA, Botting KJ, Zhang S, McMillen IC \& Morrison JL 2015a Low birth weight activates the renin-angiotensin system, but limits cardiac angiogenesis in early postnatal life. Physiological Reports $\mathbf{3}$ e12270. (doi:10.14814/phy2.12270)

Wang KC, Tosh DN, Zhang S, McMillen IC, Duffield JA, Brooks DA \& Morrison JL 2015b IGF-2R-Goq signalling and cardiac hypertrophy in the low birth weight lamb. American Journal of Physiology: Regulatory, Integrative and Comparative Physiology 308 R627-R635. (doi:10.1152/ ajpregu.00346.2014)

WHO 2014 Global status report on noncommunicable diseases 2014. In WHO Library Cataloguing-in-Publication Data. Geneva, Switzerland: WHO Press. (available at: http://www.who.int/nmh/publications/ncdstatus-report-2014/en/)

Xu J, Carretero OA, Lin CX, Cavasin MA, Shesely EG, Yang JJ, Reudelhuber TL \& Yang XP 2007 Role of cardiac overexpression of ANG II in the regulation of cardiac function and remodeling postmyocardial infarction. American Journal of Physiology: Heart and Circulatory Physiology 293 H1900-H1907. (doi:10.1152/ ajpheart.00379.2007)

Yang Y, Li T, Vu TH, Ulaner GA, Hu JF \& Hoffman AR 2003 The histone code regulating expression of the imprinted mouse Igf2r gene. Endocrinology 144 5658-5670. (doi:10.1210/en.2003-0798)

Yazawa H, Miyachi M, Furukawa M, Takahashi K, Takatsu M, Tsuboi K, Ohtake M, Murase T, Hattori T, Kato Y, et al. 2011 Angiotensin-converting enzyme inhibition promotes coronary angiogenesis in the failing heart of Dahl salt-sensitive hypertensive rats. Journal of Cardiac Failure 17 1041-1050. (doi:10.1016/j.cardfail.2011.09.002)

Young LE, Fernandes K, McEvoy TG, Butterwith SC, Gutierrez CG, Carolan C, Broadbent PJ, Robinson JJ, Wilmut I \& Sinclair KD 2001 Epigenetic change in IGF2R is associated with fetal overgrowth after sheep embryo culture. Nature Genetics 27 153-154. (doi:10.1038/84769)

Zha J, Harada H, Yang E, Jockel J \& Korsmeyer SJ 1996 Serine phosphorylation of death agonist BAD in response to survival factor results in binding to 14-3-3 not BCL-X(L). Cell 87 619-628. (doi:10.1016/S0092-8674(00)81382-3)

Zhang S, Rattanatray L, MacLaughlin SM, Cropley JE, Suter CM, Molloy L, Kleemann D, Walker SK, Muhlhausler BS, Morrison JL, et al. 2010 Periconceptional undernutrition in normal and overweight ewes leads to increased adrenal growth and epigenetic changes in adrenal IGF2/ H19 gene in offspring. FASEB Journal 24 2772-2782. (doi:10.1096/ fj.09-154294)

Zuo T, Liu TM, Lan X, Weng YI, Shen R, Gu F, Huang YW, Liyanarachchi S, Deatherage DE, Hsu PY, et al. 2011 Epigenetic silencing mediated through activated PI3K/AKT signaling in breast cancer. Cancer Research 71 1752-1762. (doi:10.1158/0008-5472. CAN-10-3573)

Received in final form 12 February 2017

Accepted 20 February 2017

Accepted Preprint published online 20 February 2017
() 2017 Society for Endocrinology Printed in Great Britain
Published by Bioscientifica Ltd. 